\title{
434 引張荷重下におけるアクチンフィラメント構造の分子動力学解析
}

Molecular Dynamics Analysis on Actin Filament Structure Under Tensile Force
○学
松田亮（京都大・院）
正 安達 泰治
(京都大·工)
井上 康博
(理研)

曽我部 正博（名古屋大・医）正 北條 正樹 （京都大·工）

Ryo MATSUDA, Taiji ADACHI, and Masaki HOJO, Dept. Mech. Eng. \& Sci. Kyoto University, Kyoto

Yasuhiro INOUE, VCAD System Research Program, RIKEN

Masahiro SOKABE, Dept. Phisiol., Nagoya University, Nagoya

Key Words: Cell Biomechanics, Actin Filament, Steered Molecular Dynamics, Tensile Force, Cofilin

\section{1. 粕 言}

細胞骨格の一種であるアクチン細胞骨格は, 力学的強度の付与, 細胞形態の維持, 細胞運動などの基本的な細胞機能を担っている. さらに, 細胞が力学的刺激を感知する際, 同構造が, その感知機 構の構成要素としての役割を果たしていると考えられており,特 に,アクチン細胞骨格の動的な再構築の重要性が示晙されている. このようなアクチンの再構築は, 生化学的因子に加えて, 力学的 因子によっても調整されている可能性が指摘されている[1]. 例え ば,アクチン細胞骨格の動的安定性に対する張力の影響を調べる ため, 骨芽細胞のアクチン細胞骨格に存在する張力を選択的に解 放する実験が行われた[2]. その結果, 張力の解放により, 同構造 の脱重合が促されることが示された. しかしながら, 力学的因子 がアクチンの重合・脱重合を調整する機構については, 切断関連 タンパク質の影響が示唆されるものの未だ明らかではない.

そこで, 本研究では, 同構造に対する力学的刺激の影響を解明 する第一歩として, アクチンモノマー14 個から構成された二重 ら旋の分子構造からなるアクチンフィラメントに着目した. ここ では, 分子動力学法を用いて, アクチンフィラメントに引張ひず み $1 \%$ 与え, 両端固定し平衡化させ, 引張ひずみの影響による 同構造二重ら旋の㧖れの変化を評価した.

\section{2. シミュレーション手法}

本研究では, 汎用分子動力学計算ソフト, NAMD2.5（イリノ イ大学)を使用した.

2.1 アクチンフィラメントの分子楛造 シミュレーションに 用いたアクチンフィラメントの分子構造は, Protein Data Bank (PDB)に登録されている $1 \mathrm{MVW}$ データを用いた. 同構造は, X 線結晶構造解析により得られたものであり,ウサギの骨格筋のア クチン分子とミオシン分子から構成されている. 同構造から, Fi シミュレーションに用いるアクチンフィラント(G-アクチン 14 個)を取り出した. このアクチンフィラメントの Z 軸方向長さは

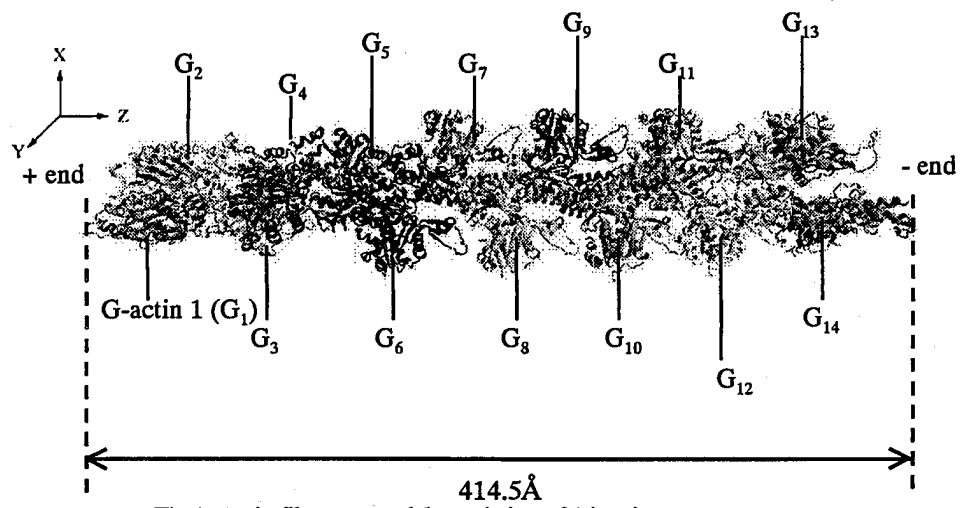

Fig.1: Actin filament model consisting of 14 actin monomers
414.5 ̊である. Fig.2 に示すように, 各 G-アクチンは, 372 個の アミノ酸残基を有している.

まず, 細胞質中における分子構造を再現するため, アクチン フィラメント周囲の直方体領域 $(\mathrm{X}$ 軸方向 $108 \AA$, Y 軸方向 $109 \AA$, $\mathrm{Z}$ 軸方向 $470 \AA$ 次水分子を配置したモデルを作成した. 次に, 境界条件を全方向周期境界とし, 環境温度を $310 \mathrm{~K}$ て等温制御し た. 時間 $2 \mathrm{~ns}$ の系の平衡化計算を行い, 引張で用いる初期構造 を得た.ここで, 時間刻み幅は, 2 [fs/step]とした.

$2 \cdot 2$ 引張手法 引張ひずみが, アクチンフィラメントの構造変 化に与える影響を検討するため, 二重ら旋構造の一端 (Fig.1 左 端）のアクチン二分子 $\left(\mathrm{G}_{1}, \mathrm{G}_{2}\right)$ の Ca原子を固定し, 他端（Fig.1 右端) のアクチン 2 分子 $\left(\mathrm{G}_{13}, \mathrm{G}_{14}\right)$ の $\mathrm{C} \alpha$ 原子に引張荷重を負荷 した. 引張方向は, アクチンフィラメント構造の中心軸（Z 軸) に平行とし，Ca原子一個につき，一定の引張荷重 $f=5 \mathrm{pN}$ を与 えた.ここで, 時間刻み幅 $\Delta t=2.0[\mathrm{fs} / \mathrm{step}]$ とし, アクチンフィ ラメント長さに対して引張ひずみ $1 \%(\mathrm{Z}$ 軸方向のアクチンフィ ラメント伸び $4.14 \AA ̊$ )を与えるまで引張荷重を負荷した. その後, 左端のアクチン 2 分子 $\left(\mathrm{G}_{1}, \mathrm{G}_{2}\right)$ のサブドメイン $\mathrm{D}_{1}, \mathrm{D}_{3}$ (Fig.2)， および右端のアクチン 2 分子のサブドメイン $\mathrm{D}_{2}, \mathrm{D}_{4}$ (Fig.2) の Ca原子をそれぞれ固定して, 平衡化計算を行った. 境界条件, 環境温度，および時間刻み幅は前節と同様の条件を用いた。

2.3 アクチン分子四の据れ角 引張ひずみの作用に対して, ア クチンフィラメント構造の変化を考察する上で, 隣り合うアクチ ン分子の成す㨝れ角に着目した. アクチン分子 $\mathrm{G}_{i}(i=1$ 14)内の サブドメイン $\mathrm{D}_{k}(k=1 \sim 4)$ 重心位置を $\bar{x}_{i k}$ として, 4 本の法線 ベクトル $n_{i l}(l=1 \sim 4)$ を 3 点 $\bar{x}_{k l}(k \neq l)$ から作られる平面に対し て直交するべクトルとする. これら法線べクトル $n_{i l}$ の和をアク チン分子 $\mathrm{G}_{i}$ 平面に対する単位法線ベクトル $n_{i}$ とし, $n_{i}$ を $X Y$ 平面 に射㔀した単位べクトルを $n_{i-X Y}$ として, 隣り合うアクチン分子 間の㨝れ角 $\theta_{i j}$ を,

$\theta_{i j}=\arccos \left(n_{i-X Y} \cdot n_{j-X Y}\right), \quad(j=i+1, i=1 \sim 13)$

と定義した.

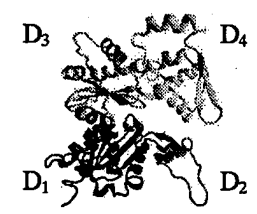

Fig.2: Subdomains of an actin monomer. $D_{1}$ includes residues $1-32,70-144,338-372, D_{2}$ includes residue $33-69, D_{3}$ inchudes residue 1 45-180, 270-337, and $\mathrm{D}_{4}$ includes residue 181-269.

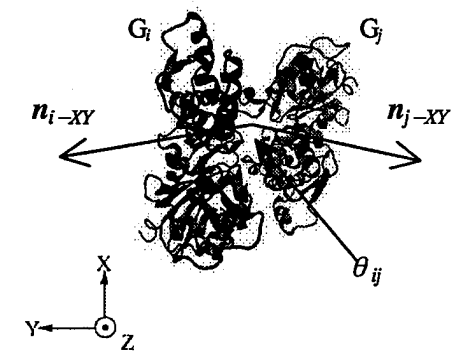

Fig.3: Rotation angle $\theta_{i j}$ between G-actin $i$ and $j$. 


\section{3. シミュレーション结果と考㲾}

$3 \cdot 1$ 引張シミュレーション 初期構造に対して引張荷重 $f=5$ $\times 372=1860 \mathrm{pN}$ を負荷した場合のアクチンフィラメントの伸び の時間変化を Fig.4に示す. 同図に示すように, 時刻 $t=197 \mathrm{ps}$ に おいて，アクチンフィラメントの伸びが長さの $1 \%$ (4.14 ̊) と なった. このときのアクチンフィラメント構造を用いて, 両端固 定の平衡化シミュレーションを行った場合のアクチンフィラメ ント構造の各時刻における RMSD 值を Fig.5 に示す. Fig.5 に示 すように, $t=1400 \mathrm{ps}$ 以降では, RMSD 值がほぼ一定值となるこ とから, 平衡に達したと考えられる.

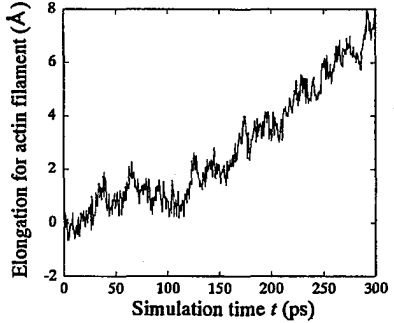

Fig.4: Change in elongation of actin filament during application of tensile force $f=1860 \mathrm{pN}$

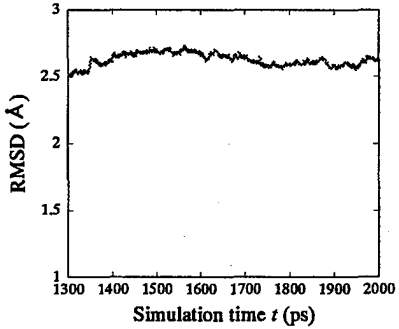

Fig.5: Change in RMSD for actin filament structure during equilibration in condition that both ends of actin filament are fixed.
$3 \cdot 2$ 引張ひずみ 1\%におけるアクチン分子の据れ角 引張ひ ずみを負荷していないアクチンフィラメント構造と引 張ひずみ $1 \%$ 負荷した同構造のアクチン分子間の平均 据れ角 $\bar{\theta}_{i j}$ を比較した. ただし, 前者の構造は, 平衡化シミュ レーションの $1.6 \sim 2.0 \mathrm{~ns}$ 間, 後者の構造は, 同構造の両端固定の シミュレーションを開始してから $1.6 \mathrm{~ns} 2.0 \mathrm{~ns}$ 間の $0.5 \mathrm{ps}$ 毎のデ 一夕数 800 を用いた. これらのデー夕から得られたアクチン分子 $\mathrm{G}_{5} \sim \mathrm{G}_{10}$ における平均の据れ角 $\bar{\theta}_{i j}$ 之標準偏差を Table 1 に示す. ただし, 変形を拘束したアクチン分子 $\mathrm{G}_{1}, \mathrm{G}_{2}, \mathrm{G}_{13}, \mathrm{G}_{14}$, とそれらに 接するアクチン分子 $\mathrm{G}_{3}, \mathrm{G}_{4}, \mathrm{G}_{11}, \mathrm{G}_{12}$ を含む㨝れ角 $\bar{\theta}_{1}$ は除いた。 れらの結果から,アクチンフィラメント構造の中央部に位置する アクチン分子 $\mathrm{G}_{6}-\mathrm{G}_{7}, \mathrm{G}_{\tau} \mathrm{G}_{8}$, および $\mathrm{G}_{8}-\mathrm{G}_{9}$ において, 引張ひずみ を負荷することにより, 平均の㨝れ角 $\bar{\theta}_{i j}$ が増加していることが わかる. Fig.6 は, これらの結果を X-Y 平面に Z 軸を中心に極座 標表示した図を, Fig.6 に示す. 張力が作用すると，据れ角が増 加することが予想されることから, アクチン分子 $\mathrm{G}_{6} \sim \mathrm{G}_{9}$ は張力 を受けていると考劣られる. また, これらの張力が作用している アクチン分子間の㨝れ角 $\theta_{i j}$ に対して, 区間幅 0.1 degree のヒス トグラムを作成し，最小二乗法を用いて正規分布に近似した. 一 例として, アクチン分子 $\mathrm{G}_{6}-\mathrm{G}_{7}$ の場合を Fig.7 7 示す. 張力の作 用により, 据れ角 $\theta_{67}$ の標准偏差が小さくなり, 正規分布のピー クが鋭くなる傾向にあることがわかった.

本計算結果より, 細胞内で作用している張力を開放するとアク

Table 1. Mean rotation angle $\bar{\theta}_{i j}$ [degree] between adjacent G-actins and standard deviation of normal distribution function.

\begin{tabular}{cccccc}
\hline Actin number $i-j$ & $5-6$ & $6-7$ & $7-8$ & $8-9$ & $9-10$ \\
\hline Equilibrium & & & & & \\
angle $\bar{\theta}_{i j-E Q}$ [degree] & 156.35 & 162.58 & 162.16 & 165.90 & 168.14 \\
S. D. & 1.06 & 1.12 & 0.57 & 1.28 & 0.66 \\
Tensile strain & & & & & \\
angle $\bar{\theta}_{i j-T E}$ [degree] & 157.66 & 166.93 & 167.98 & 168.30 & 166.89 \\
S. D. & 0.57 & 0.57 & 0.49 & 0.68 & 0.75 \\
$\bar{\theta}_{i j-T E}-\bar{\theta}_{i j-E Q}$ & 1.31 & 4.35 & 5.82 & 2.40 & -1.25 \\
\hline
\end{tabular}

チン細胞骨格が脱重合して消失する機構を考察する.アクチン細 胞骨格の切断において, 力学的因子之生化学的因子による相互作 用が指摘されており, 特に生化学的因子として, アクチン切断夕 ンパク質のコフィリンが存在する. コフィリンは, アクチンフィ ラメシトに結合することで, アクチン分子間の摸れ角 $\theta$ を $5^{\circ}$ 小 さくし，二重らせん構造を㨭ることでアクチン分子間を切断する ことが推測されている[ㄱ. 本研究において，力学的因子である引 張ひずみを負荷することで, アクチン分子間の㨝れ角 $\theta$ の摇らぎ は小さくなり, 構造体として据れにくくなるため, コフィリンが アクチンフィラメントに結合しにくくなる, あるいは, 結合して もコフィリンによる据れが起りにくくなる可能性が示唆された.

\section{4. 桔 言}

本研究では，引張ひずみ $1 \%$ 負荷したアクチンフィラメント 構造と引張ひずみを負荷していないアクチンフィラメント構造 のアクチン分子間の据れ角 $\bar{\theta}_{i j}$ を比較した. その結果, アクチン フィラメント構造の中央部に位置するアクチン分子の据れ角 $\bar{\theta}_{i j}$ は, 引張を負荷することで, 摇らぎが小さくなり, 構造体として 据れにくくなることがわかった.この結果から, 細胞内で作用し ている張力を解放したアクチン細胞骨格の脱重合の機構におい て, 張力による力学的因子が, 切断タンパク質であるコフィリン の作用を阻害する可能性が示唆された.

本研究は，一部 JST-CREST，および文部科学省科学研究費補 助金特定領域研究「マイクロ・ナノバイオメカニクスの開拓」の 援助を得た. 記して，謝意を表する.

\section{5. 考文献}

[1] Neidlinger-Wike, C. et al., J. Orthop. Res., 19, (2001), 286-293.

[2] Sato, K. et al., The 16th Bioengineering Conference, JSME, 03-38, (2004), 9-10.

[3] Bamburg, J. R. et al., Trends in Cell Biology, 9, (1999), 364-370.

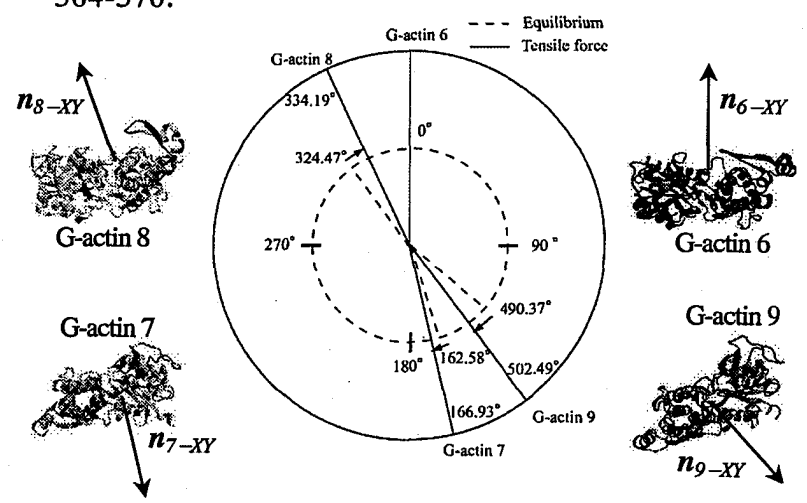

Fig.6: Comparison of angle $\theta_{i j}$ of actin 6-9 under tensile force with that of actin 6-9 during equilibration.

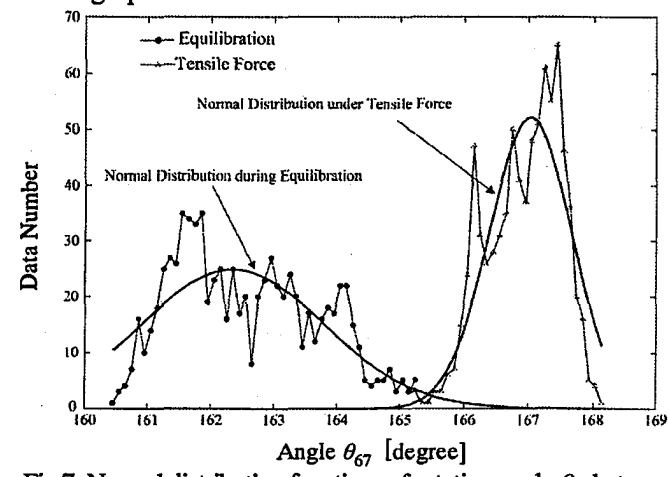

Fig.7: Normal distribution functions of rotation angle $\theta_{67}$ between G-actin 6 and 7 under tensile strain and under equilibrium. 